\title{
Pet let Dobe
}

\author{
Jasna Dominko - Baloh
}

Pred petimi leti smo v našem mestu v skromnih pogojih začeli $\mathrm{z}$ izvajanjem izobraževalnih programov za odrasle in otroke. Imeli smo vizijo, ideje, veliko znanja in volje ter sodelavce, ki so $\mathrm{z}$ nami orali ledino prvega zasebnega zavoda.

$\mathrm{V}$ prvem letu delovanja je bila naša dejavnost predvsem jezikovno izobraževanje, ki je še danes eno izmed najpomembnejših področij, pridružujejo pa se mu programi za učinkovito delo in učenje ter založništvo. Že od vsega začetka smo se zavedali, da brez razvoja in novosti ni uspeha, zato vsako leto dodajamo v ogrlico naših uspehov drobne bisere. Obseg poslovanja se je v zadnjih letih potrojil: imamo osem redno zaposlenih delavcev in več kot 200 rednih zunanjih sodelavcev.

$\mathrm{Za}$ naše mesto je pogosto značilna črnogledost, $v$ ljudeh je občutek brezperspektivnosti. Na nekaterih podrocjih je resnično hudo; prvo zdravilo, ki nam je nujno potrebno, je, da odpremo oči in se zavedamo možnosti, ki obstajajo. Zagotovo je to razvoj človeškega potenciala.

Na področju izobraževanja se v Mariboru ne moremo posebej pohvaliti, saj kar $50 \%$ prebivalcev z izobrazbo ne seže prek osnovne šole, nizko je tudi število prebivalcev s srednjo šolo. Če primerjamo Maribor $\mathrm{z}$ drugimi področji $\vee$ Sloveniji, lahko rečemo, da je to naša šibkost, ob sicer razvitem šolskem sistemu in lastni univerzi. Premalo je razvito tudi vseživljenjsko izobraževanje na različnih nivojih.

$\mathrm{V}$ vsestranskem razvoju človeškega potenciala smo v Dobi videli možnost lastnega razvoja in razvoja mesta, verjeli smo $\mathrm{v}$ to, delali in uspeli. $Z$ raznovrstno ponudbo smo $v$ zadnjih petih letih poverevali tudi potrebe po izobraževanju, širili smo znanje za otroke in odrasle.

Kot številčno majhen narod sredi Evrope imamo Slovenci izjemne možnosti za pretok dobrih idej, oblik in uspešnih resitev. Nujna je velika dovzetnost za ideje, pogoj za to pa je aktivno znanje jezikov sosednjih in drugih narodov.

Staršem smo ponudili program, ki je namenjen najmlajšim za zgodnje učenje tujega jezika.

V petih letih se je v ta program vključilo 3.300 cicibanov. Ponosni smo, da smo se v Dobi pridružili tudi strokovnim iskanjem najustreznejšega modela zgodnjega učenja tujega jezika $z$ raziskovalno nalogo, ki smo jo izvajali v dveh mariborskih vrtcih in jo zaključili $v$ minulem šolskem letu.

Za osnovnošolske otroke smo $\mathrm{v}$ petih letih ponudili jezikovne tečaje, $v$ katerih so nadaljevali v vrtcih zastavljeno učenje. Vanje se je vključilo več kot 2.300 učencev. Povsem nov je program Plus, ki smo ga pripravili za nadarjene. Ti dosegajo pri nas izvrstne rezultate.

Na področju jezikovnega izobraževanja smo naredili velik korak naprej; izboljšali smo ponudbo v smislu raznovrstnosti programa in kakovosti dela.

$\mathrm{Za}$ to področje smo si pridobili verifikacijo Ministrstva za šolstvo. Tujega jezika se je pri nas učilo več kot 4.400 odraslih. Ti se lahko v Dobi pripravljajo tudi za opravljanje mednarodnih izpitov. S tem smo se približali zahodnoevropskim standardom in jih prevzeli. Verificirani programi, stimulativno okolje, celostni učni pristop in skrbno izbrani predavatelji popeljejo udeležen- ce na pot samozavestnega komuniciranja v tujem jeziku. Izobraževanje se zaključi z izpitom za aktivno znanje.

Beseda znanje po naši oceni pomeni mnogo več kot faktografsko ali papirnato knjižno znanje. Vsebuje tudi veliko stvari, ki so nujno potrebne za zadovoljivo človekovo življenje. Zato v Dobi razvijamo in ponujamo tudi programe za spoznavanje samega sebe, svojih posebnosti in prednosti, svojih hotenj in čustev.

Le s takšnimi spoznanji lahko človek začne graditi hierarhijo svojih potreb, vrednot, aktivnosti in ciljev.

$\mathrm{Z}$ izobraževanjem za brezposelne, ki ga izvajamo v sodelovanju $z$ mariborskim zavodom za zaposlovanje, posebej razvijamo vsebine za tiste brezposelne, ki zaradi specifične osebne situacije težje najdejo zaposlitev. In teh je $v$ našem mestu veliko. Zato veliko delamo na področju motivacije in samoaktualizacije, saj jim želimo odpreti možnosti aktivnega iskanja zaposlitve.

Skupaj z nemško strokovnjakinjo smo razvili program Odkrivanja poklicnega cilja, ki se izvaja po Sloveniji. Pridobili smo licenco in v sodelovanju $\mathrm{z}$ ministrstvom za delo in republiskim zavodom za zaposlovanje izpeljali tudi izobraževanje moderatorjev.

V sodelovianju $\mathrm{z}$ Andragoškim centrom Slovenije in Zavodom za zaposlovanje Maribor izvajamo program usposabljanja za življenjsko uspešnost. V preostalih programih, ki jih ponujamo, si lahko brezposelni širijo svoje poklicno znanje in s tem postajajo bolj konkurenčni na trgu delovne sile. $V$ petih letih je bilo $v$ te programe vključenih 2.800 iskalcev zaposlitve.

Tudi v Sloveniji se že zavedamo, kako nujno je razvijanje novih oblik zadovoljevanja medčloveških odnosov in iniciativnosti, ustvarjalnosti, samostojnosti. Za Maribor je to še posebej pomembno, tako da v Dobi organiziramo študijske krožke, $v$ katerih udeleženci poleg znanja zadovoljujejo še potrebo po prijetnih družabnih stikih, pripravljamo pa tudi druge programe s področja učinkovitosti dela in učenja.

$\mathrm{V}$ zadnjih letih lahko $\mathrm{v}$ knjigarnah najdemo pravo bogastvo novih knjižnih izdaj. Temu dodajamo knjige in priročnike, ki jih izdajamo v sodelovanju $z$ nemško založbo Gabal. Odločamo se za tematiko, kako povexati osebno učinkovitost tako pri delu kot učenju. Doslej smo izdali šest knjig.

$\mathrm{Z}$ vsemi temi programi želimo $\mathrm{v}$ našem mestu prispevati $\mathrm{k}$ temu, da bi si ljudje zagotovili enako prihodnost kot $v$ kakšnem drugem mestu v Evropi.

Doslej se na področju izobraževanja kaže največja potreba po tujih jezikih in računalništvu, veliko manj pa po znanju gospodarjenja, poslovanja, komunikacije, vodenja itd. Po teh znanjih je veliko večje povpraševanje v Ljubljani ali Celju. Zato je jasno, da teh programov, ki so nujni za reševanje številnih gospodarskih vprašanj, ni mogoče prepustiti zgolj trgu. Poiskati je potrebno načine, kako spodbuditi potrebe po izobraževanju $z$ alternativnimi programi svetovanja, informiranja in motivacije ter ponudbo prilagoditi razmeram.

Pri svojem delu skrbimo za povezovanje naše izobraževalne dejavnosti z naprednimi tovrstnimi tokovi in spoznanji v svetu in za prenašanje uspešnih rešitev k nam. Skrbimo za to, da se uveljavlja kakovost in nivo najboljsih tujih sol na področjih, kjer so takšne primerjave možne. Naša dejavnost je odprta, omogoča 
individualnost, izbiro hitrosti učenja, raven dosežkov in tudi individualno delo učiteljev, prilagojeno potrebam udeležencev.

$\mathrm{Z}$ nami sodeluje vec kot 200 stalnih zunanjih sodelavcev, $\mathrm{ki}$ imajo znanje, elan in nove ideje. Prav njim gre velika zasluga za uspešno izvajanje programov.

$\mathrm{V}$ petih letih delovanja se je naših programov (tečaji, seminarji, delavnice) udeležilo več kot 13.000 udeležencev (otrok in odraslih). Pripravili smo več kot 80 različnih programov in 66.000 izobraževalnih ur.

Uspešni smo bili tudi zato, ker smo za nove projekte našli podporo pri ministrstvu za šolstvo, ministrstvu za delo, republiškem zavodu za zaposlovanje, mariborskem zavodu za zaposlovanje in andragoškem centru. Hvala vsem s prepričanjem, da bo tako tudi v prihodnje, in $z$ upanjem, da se bodo naši dejavnosti tudi na mariborski mestni občini začela odpirati vrata.

V Dobi bomo naredili vse, da bi posameznikom pomagali odpreti oči, da se bodo zavedali svojih možnosti in sposobnosti ter se razvijali tako, da se bo tudi naše mesto sposobno dinamično razvijati in kvalitetno rasti ne samo v gospodarstvu, temveč tudi v mišljenju, izobraževanju in komunikaciji. V Mariboru želimo dati prednost razvijanju znanja in sposobnosti pri prebivalcih vseh starosti. V tem prizadevanju bi zelo pomagalo, ce bi si postavili ideal »učečega se mesta«.

Z veseljem lahko povem, da v Mariboru s pomočjo Ministrstva za ふolstvo in šport ustanavljamo Središce za spodbujanje učenja, ki je za naše mesto še kako pomembno in pomeni prvi korak $\mathrm{k}$ temu idealu.

\section{Tradicionalni salzburški pogovori ○ izobraževanju odraslih}

Anita Kalpan

V Salzburgu so bili od 16. do 22. julija letos osemintrideseti salzburški pogovori o izobraževanju odraslih $\mathrm{v}$ organizaciji Zveze avstrijskih ljudskih univerz (Verband Österreichischer Volkshochschule) in pod pokroviteljstvom Evropskega urada za izobraževanje odraslih (Europäisches Buro für Erwachsenenbildung). Letošnji pogovori so bili posvečeni izredno zanimivi temi -izobraževanju odraslih kot državljanskemu gibanju. Navzoči so bili znanstveniki in strokovnjaki (skupaj 60 udeležencev) iz več evropskih držav (Avstrije, Nemčije, Belgije, Švice, Madžarske, Češke, Slovaß̌ke, Bolgarije, Slovenije, Hrvaške, Poljske, Ukrajine... pa tudi iz Japonske in Sierre Leone). V okviru napovedane teme so poleg drugega razpravljali o naslednjih interdisciplinarnih vprašanjih: Ali izobraževanje odraslih lahko poskrbi za potrebe in interese državljanov? Kako lahko izobraževanje odraslih postane podpora interakcijskim družbenim procesom in vpliva na to, da državljani postanejo bolj gibljivi in dejavni? Je lahko izobraževanje odraslih $\mathrm{v}$ zvezi s tem osnova za javno razpravo? Katere metode, načela in modeli izobraževanja odraslih so učinkoviti v procesih družbene in državljanske gibljivosti in demokratizacije družbe.

Salzburški pogovori so potekali plenamo in po skupinah. Uvodno predavanje je imel prof. dr. Johan Kade iz Nemčije, potem pa je delo potekalo $v$ treh delovnih skupinah. Na koncu je bila opravljena sinteza rezultatov dela skupin, dogovorjene pa so bile možne vsebine za prihodnje pogovore. Pripomnimo lahko še to, da je izmenjava izkušenj in spoznanj na letošnjih salzburških pogovorih potekala $v$ znamenju kritičnega vendar zelo strpnega ozraçja, kot se spodobi za prireditev $s$ takšno tradicijo in udeleženci.

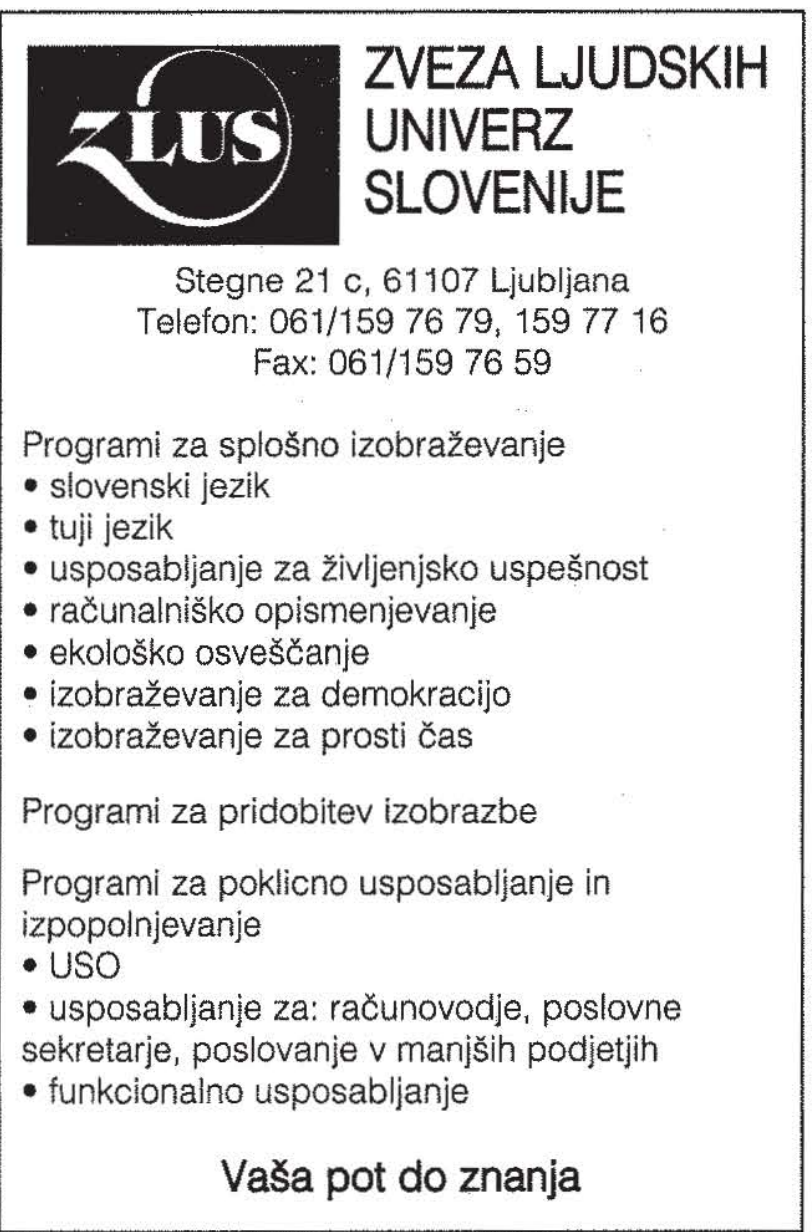

